\title{
Diagnosis of headaches in dental clinic
}

\author{
Hye-Jin Lee, Young-Gun Kim, Seong-Taek Kim* \\ Department of Orofacial Pain and Oral Medicine, Yonsei University College of Dentistry, Seoul, Republic of Korea
}

Headache disorders, one of most common disease in general population, have been developed according to many versions of international classifications. The primary headaches are those in which no consistently identified organic cause can be determined. It is divided into the following categories: (1) migraine, (2) tension-type headache, (3) cluster headache and other trigeminal autonomic cephalalgias, (4) other primary headaches. This review described a diagnosis of primary headache disorders based on International Classification of Headache Disorders (ICHD)-3 beta criteria. (J Dent Rehabil Appl Sci 2016;32(2):102-8)

Key words: headache; headache disorders, primary; migraine disorders; tension-type headache; temporomandibular joint disorders

\section{서론}

두통은 전체 인구 중 $90 \%$ 이상이 일생에 한번 이상 겪 게 되는 질환으로 문명화와 더불어 점점 증가하는 추세 이며 치과의사도 임상에서 종종 두통 환자를 접할 수 있 다. ${ }^{1}$ 그러나 이런 환자에게 치과의사로서 어떠한 정보 를 주기가 쉽지 않은 것이 사실이며, 대부분의 경우 단 순 진통제를 처방해주거나 신경과로 환자들을 의뢰하 는 것이 현실이다. 하지만 환자의 병력(history)을 세심 히 청취하고 기본적인 두통의 증상을 제대로 파악하면 organic disease에 의한 이차 두통이 아닌 원발 두통의 경우에는 진단 및 치료가 가능하다.

\section{문헌고찰}

\section{1. 원발 두통 (primary headache)과 이차 두통 (secondary headache)}

특별한 원인 질환 없이 두통 자체가 질환인 경우를 원

*Correspondence to: Seong-Taek Kim

Professor, Department of Orofacial Pain and Oral Medicine, Yonsei University College of Dentistry, 50 Yonsei-ro, Seodaemun-gu, Seoul, 03722, Republic of Korea

Tel: +82-2-2228-3110, Fax: +82-2-393-8076, E-mail: k8756050@yuhs,ac

Received: June 14, 2016/Last Revision: June 20, 2016/Accepted: June 21, 2016
발 두통이라고 하며, 뇌종양, 뇌혈관질환, 외상, 감염, 약 물 과용 등의 다른 원인에 의해 발생하는 두통을 이차 두통이라고 한다(Fig. 1). 편두통(migraine), 긴장형두통 (tension-type headache), 삼차자율신경두통(trigeminal autonomic cephalalgias) 등이 원발 두통에 해당한다. ${ }^{2}$ 일

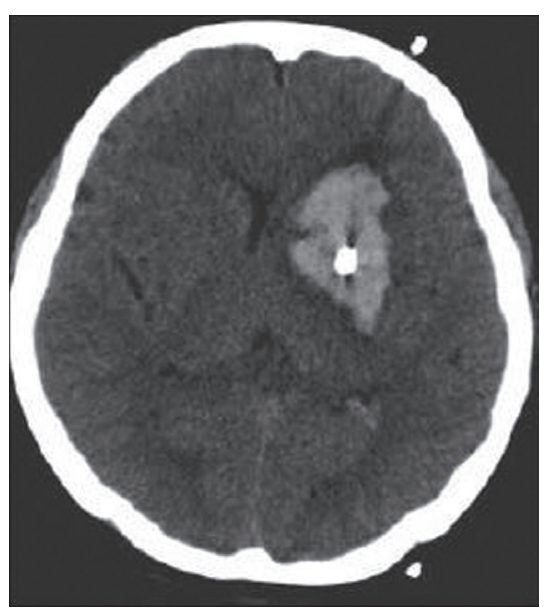

Fig. 1. Secondary headache due to cerebral hemorrhage.

Copyright@ 2016 The Korean Academy of Stomatognathic Function and Occlusion. (c) This is an Open-Access article distributed under the terms of the Creative Commons Attribution Non-Commercial License (http://creativecommons.org/ licenses/by-nc/4.0) which permits unrestricted non-commercial use, distribution, and reproduction in any medium, provided the original work is properly cited. 
반적으로 원발 두통에 비해 이차 두통의 유병률은 매우 낮다. 여기서 명심해야 할 것은 두통 환자에서 다음과 같은 소견이 나타나면 환자를 즉시 응급실로 내원시켜 야 한다는 점이다(Table 1$){ }^{3}$

\section{2. 국제두통질환분류}

국제적으로 통일된 두통 질환 분류와 진단기준은 1988년 처음 확립되었다. 국제두통학회는 1988년 모 든 두통 질환을 체계적으로 분류하고 그 진단기준을 발 표하였으며, 이를 바탕으로 2004년 국제두통질환분류 (International Classification of Headache Disorders)에 대한 개정판(ICHD-2)이 나왔다. 국제두통질환분류 제
3판(ICHD-3)은 2판에서 논쟁이 되었던 부분들에 대한 보완과 함께 ICHD-3과 같은 분류를 사용할 세계보건기 구의 국제질병분류개정판과 공조하기 위하여 정식 개정 판 이전에 베타판을 먼저 발표하였다(Table 2). ${ }^{4}$

이 분류는 계층적 구조를 가지고 있기 때문에 우선 환 자가 호소하는 증상이 14 가지의 두통질환 분류 중 1. 편 두통 혹은 2. 긴장형 두통 같이 크게 어떤 군에 속할지 결정한 후 각각의 소분류에 대해 좀 더 세밀한 진단을 하게 된다. 예를 들어 1. 편두통은 14 가지 두통질환분류 중 한가지인데 1.2 조짐 편두통과 같은 소분류를 포함하 고, 조짐편두통은 다시 1.2.1 전형조짐편두통과 같은 하 위분류로 나눠진다.

Table 1. Red flags of worrisome headache

Worrisome Headache Red Flags: "SNOOP"

Systemic symptons (fever, weight loss) or Secondary headache risk factors (HIV, systemic cancer)

Neurologic symptoms of abnormal signs (confusion, impaired alertness, or consciousness)

Onset: sudden, abrupt, or splint-second

Older: new onset and progressive headache, especially in middle-age $>50$ (giant cell arteritis)

Privous headache history or headache progression: first headache or different (change in attack frequency, severity, or clinical features)

Table 2. International headache classification (ICHD-3 beta) ${ }^{4}$

The International Classification of Headache Disorders, 3rd edition (beta version)

Part one: the primary headaches

1. Migraine

2. Tension-type headache

3. Trigeminal autonomic cephalalgias

4. Other primary headache disorders

Part two: the secondary headaches

5. Headache attributed to trauma or injury to the head and/or neck

6. Headache attributed to cranial or cervical vascular disorder

7. Headache attributed to non-vascular intracranial disorder

8. Headache attributed to a substance or its withdrawal

9. Headache attributed to infection

10. Headache attributed to disorder of homoeostasis

11. Headache or facial pain attributed to disorder of the cranium, neck, eyes, ears, nose, sinuses, teeth, mouth or other facial or cervical structure

12. Headache attributed to psychiatric disorder

Part three: painful cranial neuropathies, other facial pains and other headaches

13. Painful cranial neuropathies and other facial pains

14. Other headache disorders 
1) 편두통

(1) 진단

임상적으로 편두통은 흔한 중증 원발 두통 질환이다. 세계질병부담연구에 따르면 전세계적으로 편두통은 3 번째로 유병률이 높고, 장애를 유발하는 모든 질환 중 7 위를 차지했다. 편두통은 편두통 진단 기준을 만족하는 두통 발작이 최소한 5 번 이상 일어난 경우 진단할 수 있 다(Table 3). (1) 4 - 72시간 지속되는 두통이 주로 (2) 편 측, (3) 중등도에서 심도 강도, (4) 박동성 양상으로 나타 나고 (5) 걷거나 계단을 오르는 등의 일상의 신체 활동에 의해 통증이 악화되며, (6) 두통이 있는 동안 구역 또는 구토, 빛공포증과 소리공포증 중 한 가지 이상을 동반되 는 것이 전형적인 특징이다.
(2) 기전

편두통의 발병기전으로 삼차신경혈관계 이론(trigeminovascular theory)이 비교적 많은 부분에서 받아들여지 고 있다. 편두통 환자들은 유전적 또는 환경적 인자에 의해 편두통 발작에 대한 뇌의 역치가 낮아져 있고, 일 반인과는 달리 대뇌 피질신경세포의 과흥분성(cortical neuronal hyperexcitability)을 가지고 있다. 자극이 가해 진 대뇌피질에서 일시적으로 전기적 활동성 감소가 발 생된 후 억제된 전기적 활동성이 자극부위로부터 파형 의 형태를 지니며 주변으로 번져나가는 겉질확산억제 (cortical spreading depression)가 일어나며, 겉질확산억 제로 인해 전기적 활동성이 감소된 부위에서는 국소적 으로 혈류 감소가 동반된다(Fig. 2).

Table 3. Diagnostic criteria for migraine without aura ${ }^{4}$

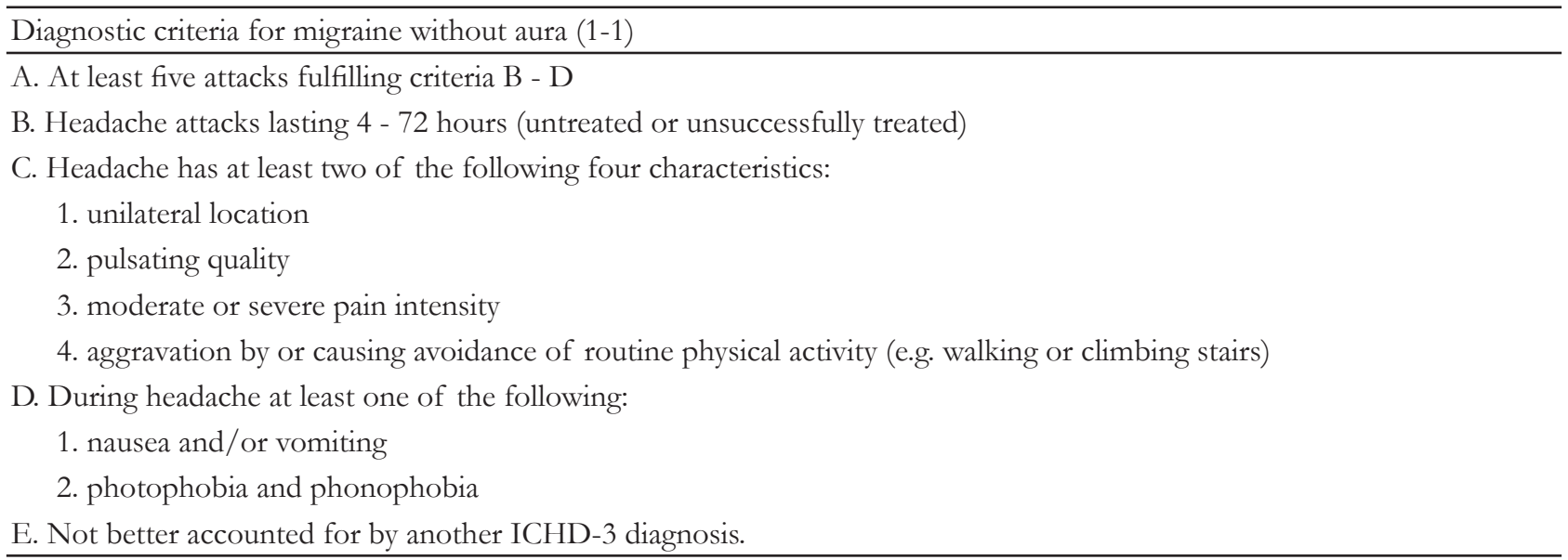

A

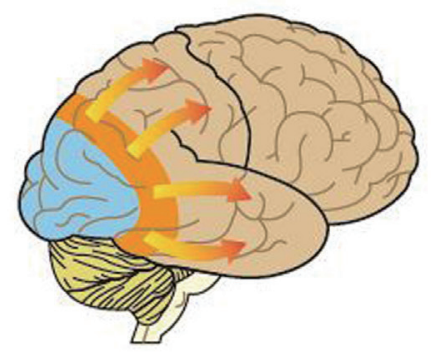

C

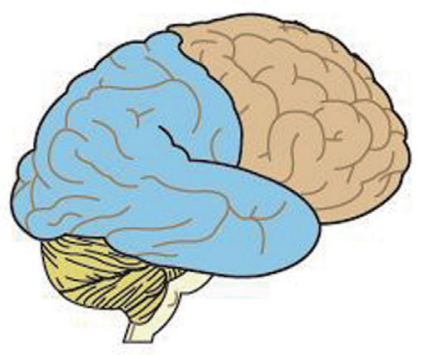

B

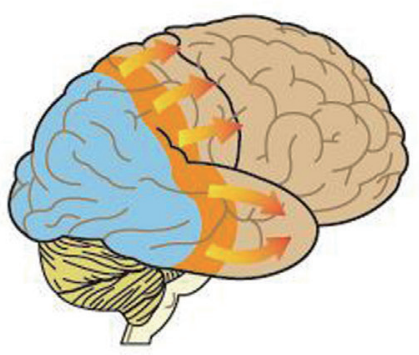

D

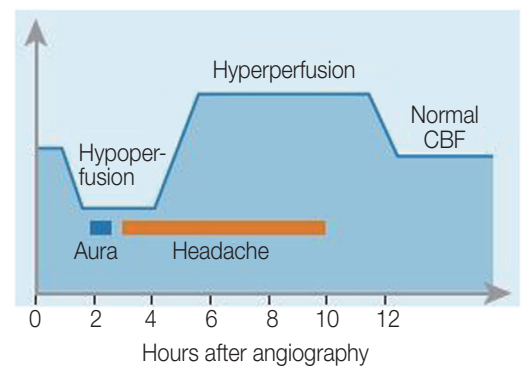

Fig. 2. Cerebral blood flow (CBF) during aura. 
국소적 혈류의 감소는 겉질확산억제가 이미 경과하 여 전기적 활동성이 정상화된 후에도 일정시간 이상 유 지되는데, 이것은 편두통 환자에서 나타나는 편두통 조 짐(Aura, Fig. 3)과 시간적 연관성이 있는 것으로 밝혀졌 다. ${ }^{5}$

조짐 편두통은 전체 편두통의 약 $20 \%$ 정도만을 차지 하고 있는데 무조짐편두통에서는 겉질확산억제가 소뇌 나 임상표현형이 약한 대뇌부위에서 시작되어 비특이적 인 어지럼증으로 간과되거나 증상으로 인식되지 못하는 것으로 설명할 수 있다. 임상적으로 확인된 무조짐편두 통의 예방약제들을 투여함으로써 겉질확산억제가 억제 되는 실험결과들을 통해서 그러한 가능성을 고려해 볼 수 있다.

두개강 내에 존재하는 통증에 예민한 혈관들은 주로 삼차 신경절로 연결되어 있는데, 겉질확산억제로 인해 두피 및 두개 부위 혈관에 분포하는 삼차 신경의 말단 이 자극되면, 특정 신경전달물질들이 방출되고 이 물질 들이 혈관확장, 혈장의 혈관 밖 수축 및 염증 반응을 유 도하여 신경인성 염증반응(neurogenic inflammation)을 일으켜 두통이 일어난다는 것으로 편두통의 발생 기전 을 설명하고 있다.

A

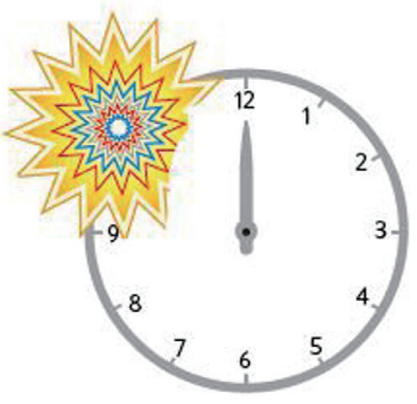

C

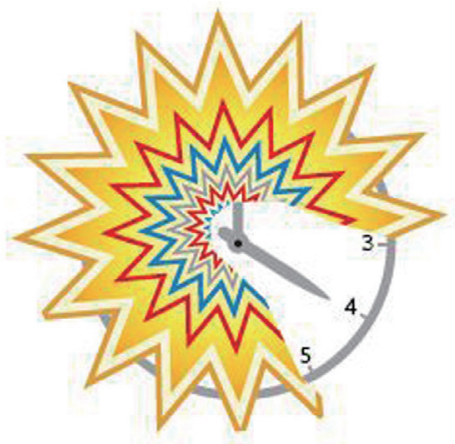

편두통 환자들에서 어떤 원인이 대뇌피질의 과흥분성 을 만들어내는지는 아직까지 명확하지 않은데, 이에 대 하여 유전적인 소인이 있을 것이라는 가능성이 제시되 고 있다. 매우 드물게 발생하는 편두통의 한 유형인 가 족편마비편두통(familial hemiplegic migraine)에 관계되 는 유전자가 알려져 있다.

\section{2) 긴장형 두통}

일반 인구의 평생 유병률이 $30-78 \%$ 에 달하는 매우 흔한 두통으로 정확한 기전은 아직 밝혀지지 않았다. 두 통의 양상은 주로 '무겁다' , '짓누르는 것 같다' , '조인 다' '어깨에 무엇을 올려놓은 것 같다' 등으로 표현되 기 때문에 이전에는 신경성 두통, 스트레스 두통, 긴장 성 두통 등으로 불렸다. 하지만 최근 연구들에서 일회 성으로 나타나는 삽화성 긴장형 두통(episodic tensiontype headache)은 주로 스트레스와 연관되어 있으나, 만 성 긴장형두통은 중추성 요인과 관련되어 있는 것으로 추정하고 있다. 두개 주변 근육 근막 조직에서 오는 유 해한 자극으로 인하여 척수후근 신경세포(dorsal horn neuron)들이 감작되어 정상적인 상태에서는 느끼지 않 아야 될 정도의 자극에 통증을 느끼게 되는 것으로 발생 기전을 설명하고 있다.
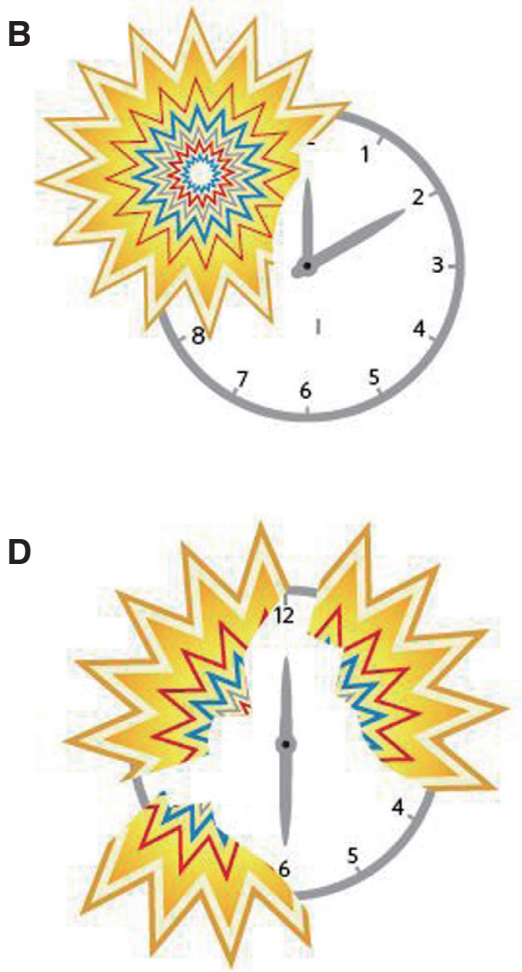

Fig. 3. Visual aura in migraine patient. 
긴장형 두통은 (1) 전형적으로 양측 위치, (2) 경도에서 중등도 강도, (3) 압박하고 조이는 느낌(비박동성)의 통 증이 (4) 수분에서 수 일간 지속되며, (5) 통증은 걷기나 계단 오르기 같은 일상 신체활동에 의해 악화되지 않고, (6) 구역이나 구토를 동반하지 않는다. (7) 빛 공포증이나 소리공포증 중 한 가지는 있을 수 있다.

고빈도삽화긴장형두통(frequent episodic tension-type headache)는 종종 무조짐편두통(migraine without aura) 과 공존한다. 편두통 치료는 긴장형두통 치료와 치료 방 법이 다르므로 이 두 가지 두통을 구별하고, 각 두통에 맞춘 올바른 치료를 선택할 수 있도록 환자를 교육하여 약물과용두통의 발생을 예방하여야 한다.

\section{3) 삼차자율신경두통}

편측의 안와, 안와위, 측두부에 발생하는 심한 통증 발 작과 종종 동측으로 동반되는 두개부 부교감자율신경 소견(결막충혈, 눈물, 코막힘, 콧물, 이마와 얼굴의 땀, 동공수축, 눈꺼풀처짐, 눈꺼풀 부종)을 공통적으로 보인 다. 군발두통(cluster headache), 돌발반두통(Paroxysmal hemicrania) 등이 이에 속한다.

4) 턱관절질환에 기인한 두통

국제두통질환분류 11. 두개골, 목, 눈, 귀, 코, 부비동,
치아, 입 또는 기타 얼굴 및 경부 구조물의 질환에 기인 한 두통 또는 얼굴통증은 두통이 두개골, 경부, 얼굴, 목, 눈, 귀, 코, 부비동, 치아 또는 구강 질환과 밀접한 시간 연관성을 가지고 처음으로 발생하거나 만성화되었거나 또는 악화(보통 빈도와/또는 강도가 2배 이상 증가된 경 우)되었을 때 그 질환에 기인한 이차두통으로 분류한다. 턱관절 및 저작근 부위 통증을 주소로 치과에 내원하는 환자들이 증가하는 추세로 치과의사가 이러한 질환을 가진 환자를 직접적으로 진찰할 가능성이 증가되었다 (Table 4).

5) 만성두통과 약물과용두통

앞에서 살펴본 바와 같이 편두통/긴장성 두통/군발 두통의 특징적인 양상을 보이는 두통이 3 개월을 초과하 는 기간 동안 한달에 15 일 이상 발생한 경우 이러한 두 통을 만성 편두통(1.3)/만성 긴장형 두통(2.3)/만성 군 발두통(3.1.2)이라고 진단할 수 있다(각 진단명 뒤의 번 호는 ICHD-3의 code를 의미함).

두통의 급성 또는 대증 치료 약물을 규칙적으로 과용 한(약물의 종류에 따라 한 달에 10 일 이상 또는 15 일 이 상) 결과로 3 개월 이상의 기간 동안 한달에 15 일 이상 발생한 두통은 약물과용두통(8.2)으로 진단 내릴 수 있 다. ${ }^{3}$

Table 4. Headache attributed to temporomandibular disorder (TMD) ${ }^{4}$

11.7 Headache attributed to temporomandibular disorder (TMD)

Description:

Headache caused by a disorder involving structures in the temporomandibular region.

Diagnostic criteria:

A. Any headache fulfilling criterion $C$

B. Clinical and/or imaging evidence of a pathological process affecting the temporomandibular joint (TMJ), muscles of mastication and/or or associated structures

C. Evidence of causation demonstrated by at least two of the following:

1. headache has developed in temporal relation to the onset of the temporomandibular disorder

2. either or both of the following:

a) headache has significantly worsened in parallel with progression of the temporomandibular disorder

b) headache has significantly improved or resolved in parallel with improvement in or resolution of the temporomandibular disorder

3. the headache is produced or exacerbated by active jaw movements, passive movements through the range of motion of the jaw and/ or provocative manoeuvres applied to temporomandibular structures such as pressure on the TMJ and surrounding muscles of mastication

4. headache, when unilateral, is ipsilateral to the side of the temporomandibular disorder

D. Not better accounted for by another ICHD-3 diagnosis.

ICHD, international classification of headache disorders. 
약물과용두통의 진단은 임상적으로 중요한 의미를 갖 는다. 3 개월 이상의 기간 동안 한달에 15 일 이상 두통이 발생하는 환자의 약 절반 정도가 약물과용두통에 해당 한다. 만성편두통 환자의 $50 \%$ 정도가 관련 약물을 중단 하면 삽화편두통으로 변한다. 약물과용두통 진단기준과 다른 만성 두통(대부분 만성 편두통 또는 만성 긴장형두 통)의 진단 기준을 모두 충족한다면, 약물과용두통과 만 성편두통 또는 약물과용두통과 만성 긴장형두통으로 진 단할 수 있다.

약물과용두통의 원인과 결과에 대한 간단한 조언이 치료의 필수적인 부분이 되기 때문에 두통이 빈번한 환 자들의 경우 복용 약물에 대한 병력청취가 두통을 치료 하는데 있어 매우 중요하다.

\section{결론}

치과에 내원하는 환자들 중 종종 두통을 동반 증상으 로 호소하는 경우가 있다. 본 종설은 최근 개정된 국제 두통학회 ICHD-3 beta 분류법으로 두통을 분류하였고 이중 응급하거나 생명에 위협적인 이차성 두통의 감별 법 및 일반적인 일차성 두통의 진단에 관하여 기술하였 다. 무엇보다도 치료에 앞서 정확한 진단이 반드시 선행 되어야 한다.

\section{References}

1. Lee TG, Chung KC, Choi JW. Prevalence of migraine in Korean adults: a nationwide survey. Korean J Headache 2000;1:57-66.

2. The Korean Headache Society. Korean version of international classification of headache disorders. 2nd ed. Seoul; Medical publishing; 2005. p. 1-199.

3. Silberstein SD, Lipton RB, Dalessio DJ. Overview, diagnosis, and classification. In: Silberstein SD, Lipton RB, Dalessio DJ, editors. Wolff's headache and other head pain. 7th ed. Oxford; Oxford University Press; 2001. p. 20.

4. Headache Classification Committee of the International Headache Society (IHS). The international classification of headache disorders, 3rd edition (beta version). Cephalalgia 2013;33:629-808.

5. Goadsby PJ. Migraine pathophysiology. Headache 2005;45:S14-24.

6. Silberstein SD. Migraine pathophysiology and its clinical implications. Cephalalgia 2004;24 Suppl 2:27.

7. Dichgans M, Freilinger T, Eckstein G, Babini E, Lorenz-Depiereux B, Biskup S, Ferrari MD, Herzog J, van den Maagdenberg AM, Pusch M, Strom TM. Mutation in the neuronal voltage-gated sodium channel SCN1A in familial hemiplegic migraine. Lancet 2005;366: 371-7. 


\section{치과임상에서의 두통의 진단}

\section{이혜진, 김영건, 김성택*}

연세대학교 치과대학 구강내과학교실

두통은 전체 인구중 상당수가 일생에 한번 이상 겪게되는 질환으로, 계속하여 논의되고 개정되어 현재까지 국제적인 분류법이 마련되어 왔다. 원발두통은, 다른 원인질환에 의하지 않은 통증을 의미하며, 다음과 같이 분류할 수 있다: 1) 편두통 2) 긴장형두통 3) 군발두통과 기타 삼차자율신경두통 4) 기타 원발두통. 한편 턱관절장애에 기인한 두통 및 약 물 과용 두통은 두통의 원인이 기질적인 경우로 이차성 두통에 분류된다. 본 종설에서는 국제두통질환분류 제 3 판의 베 타판(ICHD-3 beta)에 근거한 두통의 진단에 대하여 고찰해보고자 한다.

(구강회복응용과학지 2016;32(2):102-8)

주요어: 두통; 원발두통; 편두통; 긴장형두통; 측두하악관절장애 